\title{
Carbimazole-induced myositis in the treatment of Graves' disease: a complication in genetically susceptible individuals?
}

Adoree Yi Ying $\underline{\mathrm{Lim}}^{1}$, MBBS, MRCP, Peng Chin $\underline{\mathrm{Kek}}{ }^{1}$, MBBS, MRCP, Abel Wah Ek $\underline{S o h}^{1}$, MBBS, MRCP

\begin{abstract}
A 24-year-old Chinese woman with Graves' disease presented with myositis two months after treatment with carbimazole. The patient's myositis resolved with hydration and cessation of carbimazole. No other causes of myositis were found, and a change in the medication to propylthiouracil was uneventful. Review of the literature suggests a possible genetic susceptibility, as the majority of reported cases are Asian in origin, similiar to patients who present with thyrotoxic periodic paralysis. Changing the antithyroid drugs (ATDs) administered, decreasing the dose of pre-existing ATDs in the treatment regimen or addition of levothyroxine has been shown to result in clinical improvement of this complication. These observations suggest various mechanisms of carbimazoleinduced myositis in the treatment of Graves' disease, including the direct effect of ATDs on myocytes, immune-related responses secondary to ATDs and rapid decrements in thyroid hormone, with ensuing myositis.
\end{abstract}

Keywords: antithyroid drugs, carbimazole, thyrotoxicosis treatment complications, myositis, Graves'disease

\section{INTRODUCTION}

Patients with thyroid dysfunction may present with musculoskeletal complaints. This is due to the fact that both hypo- and hyperthyroidism may cause signs and symptoms of neuromuscular dysfunction, as skeletal muscle is a target tissue for thyroid hormone. ${ }^{(1-3)}$ Hypothyroid-induced myopathy often presents with myalgia and raised serum levels of creatine kinase $(\mathrm{CK}){ }^{(3)}$ but elevation of CK levels occurs much less frequently in hyperthyroid-induced myopathy. ${ }^{(4)} \mathrm{CK}$ elevation may occur as a complication of thyroid storm, which is precipitated by dehydration and electrolyte imbalance. ${ }^{(2)}$ Although it is relatively common to encounter myositis as a complication of thyrotoxic periodic paralysis (TPP) in the Asian population, ${ }^{(5,6)}$ the development of myositis after treatment of Graves' disease (GD) is rare. To date, the exact cause for this remains uncertain.

\section{CASE REPORT}

A 24-year-old Chinese woman presented to her primary care physician in January 2008 with increased sweating, increased appetite, hand tremors and heat intolerance. She was found to be both clinically and biochemically hyperthyroid, and a clinical diagnosis of GD was made, although the patient's serum had not been sent for histopathological examination of thyroid-stimulating hormone (TSH)-receptor antibodies at that time. She was subsequently started on carbimazole $30 \mathrm{mg}$ a day. At the time of the diagnosis, her free thyroxine (FT4) level was $52.9 \mathrm{pmol} / \mathrm{L}$ (normal range [NR] 9.0-25.0 pmol/L) and her TSH level was suppressed at $0.01 \mathrm{mIU} / \mathrm{L}(\mathrm{NR} 0.40-4.70 \mathrm{mIU} / \mathrm{L})$. Results of the repeat

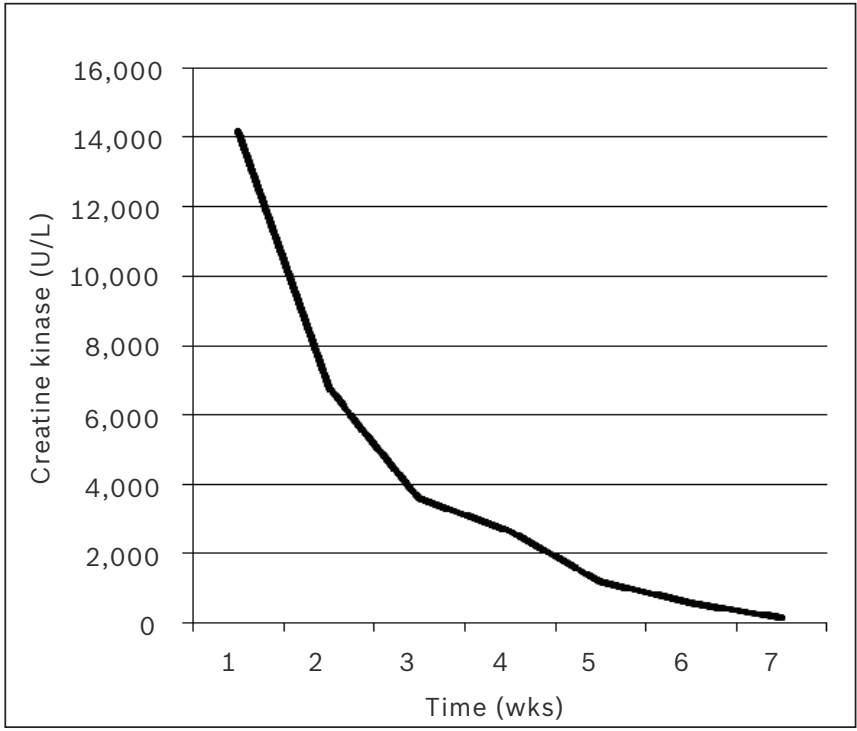

Fig. 1 Graph shows the trend of creatine kinase level in the patient.

thyroid function test on the same platform one month later showed a sharp fall in the patient's FT4 level to $17.9 \mathrm{pmol} / \mathrm{L}$, with TSH still suppressed.

The patient presented to our institution in March 2008, two months after the diagnosis, with a two-week history of cramps and weakness in all her limbs, which impeded ambulation. There was no rash, fever or joint pain; neither did she have a personal or family history of other autoimmune diseases. She denied a history of ingesting other medications, over-the-counter supplements or traditional medications. On clinical examination, she was euthyroid, without the presence of goitre, ophthalmopathy or pretibial myxoedema.

${ }^{1}$ Department of Endocrinology, Singapore General Hospital, Outram Road, Singapore

Correspondence: Dr Adoree Yi Ying Lim, Associate Consultant, Department of Endocrinology, Singapore General Hospital, Outram Road, Singapore 169608. adoree.lim.y.y@sgh.com.sg 
However, she had symmetrical proximal myopathy, with lower limbs that were weaker than her upper limbs (modified Medical Research Council scores of 2/5 and 4/5, respectively). No other demonstrable neurological findings were found. There was also no joint swelling or demonstrable tenderness, and no rash that would suggest vasculitis. Laboratory investigations revealed a markedly raised CK level of 14,203 U/L (NR 38-164 U/L), and an FT4 level of $10.4 \mathrm{pmol} / \mathrm{L}$ (NR 9.6-19.1 pmol/L), with TSH level suppressed at $<0.006 \mathrm{mIU} / \mathrm{L}$ (NR $0.36-3.24 \mathrm{mIU} / \mathrm{L}$ ). Additionally, the patient's TSH-receptor antibodies were positive at $7.3 \mathrm{IU} / \mathrm{L}$ (NR 0.0-1.5 IU/L). Her full blood count, electrolytes and erythrocyte sedimentation rate were unremarkable.

Intravenous hydration was administered to the patient and carbimazole was discontinued, as it was suspected to be a possible cause of the patient's rhabdomyolysis. The cessation of carbimazole resulted in a gradual resolution of symptoms, with repeat CK analysis showing rapid improvement (Fig. 1). Autoimmune markers such as double-stranded DNA antibody, nuclear antibody, Ro antibody, La antibody, ribonucleoprotein antibody, and cardiolipin immunoglobulin G ( $\lg G$ ) and $\lg M$ antibodies were negative. Electromyography of the patient's upper and lower limb muscles showed myopathic changes, and propylthiouracil (PTU) was administered in place of carbimazole. Two months later, the patient's CK level was normalised to $90 \mathrm{U} / \mathrm{L}$ and her FT4 level was $10.8 \mathrm{pmol} / \mathrm{L}$, but TSH remained suppressed at $<0.006 \mathrm{mU} / \mathrm{L}$. The sustained TSH suppression could have been due to the circulating TSH-receptor antibodies. Moreover, the patient admitted to being unable to fully comply with PTU dose of three times a day. She has since been on PTU treatment without recurrence of myositis.

\section{DISCUSSION}

Although painless myopathy with normal CK levels rarely occurs in patients with untreated hyperthyroidism, ${ }^{(4)}$ reports of myositis in patients undergoing treatment for hyperthyroidism are even rarer. These reports include patients treated with carbimazole (a prodrug of methimazole) and those treated with other thionamides. ${ }^{(7-13)}$ Methimazole and PTU, two relatively safe compounds, are commonly used to treat hyperthyroidism. The frequently encountered side effects of thionamides include rash, joint pain, raised serum transaminases and agranulocytosis. Agranulocytosis occurs in $0.1 \%-0.3 \%$ of patients treated with either PTU or methimazole. ${ }^{(14)}$ Myositis as a complication in the treatment of hyperthyroidism is more rarely encountered than agranulocytosis.

Table I presents previously published reports on patients with ATD-induced myositis and their management. ${ }^{(7-13)}$ Patients were started on high-dose antithyroid drugs (ATDs) (e.g. methimazole or carbimazole $30 \mathrm{mg}$ once a day, or PTU $100 \mathrm{mg}$ thrice a day), after which they experienced an improvement of their thyroid function, but subsequently developed symptomatic myopathy. Similarly, our patient received standard high-dose carbimazole (30 mg/day) and developed symptoms of myopathy within two months. Replacement of ATDs from one thionamide to another ${ }^{(8,11)}$ (as was done in our case), reduction of ATD dose ${ }^{(9,11)}$ and addition of levothyroxine to the treatment regimen, ${ }^{(8,9,12)}$ all appeared to result in clinical improvement. However, there has yet to be any satisfactory explanation for the patients' elevated CK levels.

The paucity of such cases in the general treatment population suggests that ATD-induced myositis in the treatment of GD only develops in susceptible individuals. To date, only one study has reported ATD-induced myositis in a male patient. ${ }^{(8)}$ While this is likely due to a female preponderance in thyroid disease, a possible link between gender and ATDinduced myositis cannot be ruled out. Several studies, such as the present case, involved patients of Asian ethnicity, ${ }^{(7-9,13)}$ which suggests a possible genetic preponderance for the development of ATD-induced myositis. Such an observation has also been made by Shaheen and Kim. ${ }^{(12)}$ Indeed, the ethnic spread appears to mirror the ethnic epidemiology of TPP. Patients with TPP are often young (aged 20-40 years) and of Asian descent. ${ }^{(5)}$ While the exact mechanism for the development of TPP has yet to be fully elucidated, genetic mutations, such as a mutation in potassium channel Kir2.6, have been found to confer susceptibility to TPP,(15) and may suggest that ethnic differences confer a predilection for the development of neuromuscular abnormalities in the presence of thyroid disease. However, it is notable that TPP typically occurs in male patients, as opposed to ATD-induced myositis, which predominantly occurs in female patients. To the best of our knowledge, there are no reports of patients who have developed both TPP and ATD-induced myositis concurrently.

Various treatment methods for myositis have been used with success, suggesting that myositis resulting from treatment of hyperthyroidism could be caused by various mechanisms. Suzuki et al have postulated the following possible disease mechanisms: (a) direct toxic effect of specific ATDs on myocytes; (b) immune-related responses secondary to ATDs; and (c) rapid decrements in circulating thyroid hormone levels, with ensuing myositis. ${ }^{(8)}$ It is indeed possible that some patients may be susceptible to the direct action of specific ATDs on their myocytes, as ATDs may cause lysis of myocytes, resulting in a rise in CK levels. ${ }^{(8)}$ This would account for the clinical improvement observed in patients whose treatment was switched from one ATD to another, as in our case. This mechanism, however, does not account for the improvement seen in patients who were continued on the same ATD, but with addition of levothyroxine. Apart from their direct effect on thyroid hormone secretion, ATDs have also been used in the treatment of GD due to their 
Table I. Summary of reported cases of ATD-induced myositis.

\begin{tabular}{|c|c|c|c|c|c|c|}
\hline Study & $\begin{array}{l}\text { Age } \\
\text { (yrs)/gender }\end{array}$ & Ethnicity & Thyroid antibody & $\begin{array}{l}\text { Time before } \\
\text { symptom onset }\end{array}$ & Dose of ATD & Treatment \\
\hline Present & 24/female & Chinese & Positive & 2 mths & $\begin{array}{l}\text { Carbimazole, } \\
30 \mathrm{mg} / \text { day }\end{array}$ & Resolved with PTU \\
\hline Kung(7) & 42/female & Chinese & $\begin{array}{l}\text { Case described } \\
\text { as GD; } \\
\text { antibodies } \\
\text { not reported }\end{array}$ & 2 mths & $\begin{array}{l}\text { Carbimazole, } \\
30 \mathrm{mg} / \text { day }\end{array}$ & $\begin{array}{l}\text { Resolved with cessation of } \\
\text { carbimazole; subsequently treated } \\
\text { with carbimazole and levothyroxine }\end{array}$ \\
\hline \multirow[t]{4}{*}{$\begin{array}{l}\text { Suzuki } \\
\text { et al(8) }\end{array}$} & 44/male & Japanese & $\begin{array}{l}\text { Case described } \\
\text { as GD; } \\
\text { antibodies } \\
\text { not reported }\end{array}$ & $2 w k s$ & $\begin{array}{l}\text { Methimazole, } \\
\text { dose unknown }\end{array}$ & $\begin{array}{l}\text { Improved with reduced dose; recurred } \\
\text { after switch to PTU; finally resolved } \\
\text { with decreased dose of methimazole } \\
\text { and addition of levothyroxine }\end{array}$ \\
\hline & $27 /$ female & Japanese & & 2 mths & $\begin{array}{l}\text { Methimazole, } \\
30 \mathrm{mg} / \text { day }\end{array}$ & $\begin{array}{l}\text { Resolved with reduced dose and } \\
\text { addition of levothyroxine }\end{array}$ \\
\hline & 26/female & Japanese & & $1 \mathrm{mth}$ & $\begin{array}{l}\text { Methimazole, } \\
30 \mathrm{mg} / \text { day }\end{array}$ & $\begin{array}{l}\text { Resolved with reduced dose and } \\
\text { addition of levothyroxine }\end{array}$ \\
\hline & 20/female & Japanese & & $1 \mathrm{mth}$ & $\begin{array}{l}\text { Methimazole, } \\
30 \mathrm{mg} / \text { day }\end{array}$ & $\begin{array}{l}\text { Resolved with addition of levothyroxine; } \\
\text { methimazole dose remained unchanged }\end{array}$ \\
\hline \multirow[t]{2}{*}{$\begin{array}{l}\text { Mizuno } \\
\text { et al }{ }^{(9)}\end{array}$} & $12 /$ female & Japanese & Positive & $1 \mathrm{mth}$ & $\begin{array}{l}\text { Methimazole, } \\
30 \mathrm{mg} / \text { day }\end{array}$ & Resolved with reduced dose \\
\hline & 14/female & Japanese & Positive & $1 \mathrm{mth}$ & $\begin{array}{l}\text { Methimazole, } \\
30 \mathrm{mg} / \text { day }\end{array}$ & $\begin{array}{l}\text { Persisted with PTU; resolved with } \\
\text { addition of levothyroxine }\end{array}$ \\
\hline $\begin{array}{l}\text { Shergy } \\
\text { et al }\left.\right|^{(10)}\end{array}$ & $35 /$ female & Caucasian & Negative & $2 w k s$ & $\begin{array}{l}\text { PTU, } \\
100 \mathrm{mg} \text { TID }\end{array}$ & $\begin{array}{l}\text { Cessation of PTU; resolved with } \\
\text { prednisolone and radioactive iodine }\end{array}$ \\
\hline \multirow[t]{3}{*}{$\begin{array}{l}\text { Page } \\
\text { et al(11) }\end{array}$} & 39/female & Unknown & Positive & $1 \mathrm{wk}$ & $\begin{array}{l}\text { Carbimazole, } \\
30 \mathrm{mg} / \text { day }\end{array}$ & Resolved with PTU \\
\hline & 28/female & Unknown & Positive & $\begin{array}{l}3 \text { mths, } \\
\text { intermittently }\end{array}$ & $\begin{array}{l}\text { Carbimazole, } \\
30 \mathrm{mg} / \text { day }\end{array}$ & Resolved with PTU \\
\hline & $18 /$ female & Unknown & Negative & $1 \mathrm{mth}$ & $\begin{array}{l}\text { Carbimazole, } \\
\text { dose unknown }\end{array}$ & Resolved with reduced dose \\
\hline $\begin{array}{l}\text { Shaheen } \\
\text { et a|(12) }\end{array}$ & 24/female & Caucasian & Positive & $3 w k s$ & $\begin{array}{l}\text { PTU, } \\
50 \mathrm{mg} \text { BID }\end{array}$ & $\begin{array}{l}\text { Resolved with levothyroxine that } \\
\text { was started post thyroidectomy }\end{array}$ \\
\hline $\begin{array}{l}\text { Pasquier } \\
\text { et al|(13) }\end{array}$ & $36 /$ female & Laotian & Positive & $1 \mathrm{mth}$ & $\begin{array}{l}\text { Carbimazole, } \\
60 \mathrm{mg} \text { tapered } \\
\text { to } 45 \mathrm{mg} / \text { day }\end{array}$ & Resolved with PTU \\
\hline
\end{tabular}

ATD: antithyroid drug; BID: two times a day; GD: Graves' disease; PTU: propylthiouracil; TID: three times a day

immunomodulatory effects. It is therefore conceivable that the immunosuppressive effects of ATDs may cause myositis. Additionally, myositis has been largely reported in autoimmune thyroid disease, thus suggesting the possibility of immune involvement in myositis. However, this mechanism does not explain the resolution of myositis in patients who were continued on ATDs and treated with additional levothyroxine. ${ }^{(8)}$ The decrease in circulating thyroid hormone levels and subsequent development of a relatively hypothyroid state has been widely discussed in the literature. In the four cases described by Suzuki et $\mathrm{al}^{\left({ }^{(8)}\right.}$ the diminution of serum T4 levels was followed by muscular symptoms, and thus the authors postulated that the rapid decrease in the concentration of thyroid hormone may have induced a temporary hypothyroid state with resultant elevation of CK levels. Other case reports have also observed a sudden decrease in thyroid hormone levels, resulting in acute myopathy in patients with GD who were treated with radioactive iodine-131. ${ }^{(7,16)}$ It is possible that discrepant serum and tissue thyroid hormone levels can cause muscle pain, cramps and elevation of CK levels. ${ }^{(8)}$

Shaheen and $\mathrm{Kim}^{(12)}$ hypothesised that patients who develop relative hypothyroidism could be deficient in the transport and/or production of local triiodothyronine in the skeletal muscle, and suggested that this syndrome is underreported. This mechanism of relative hypothyroidism as a cause of myositis is certainly plausible and could account for the clinical improvement seen in patients who have levothyroxine added to their treatment regimen. Nevertheless, further investigations are necessary in order to elucidate the pathophysiology of such an occurrence. If the development of a relatively hypothyroid state is indeed the causative factor in patients who develop myositis during treatment for GD, we could opt to treat such patients less aggressively and attempt to achieve a more gradual control of thyroid function. In our case, the plausible mechanism of myositis is the direct toxic effect of ATDs on myocytes, as the patient's myositis resolved rapidly when carbimazole 
was replaced with PTU. Additionally, her FT4 levels during the first month of treatment fell rapidly from more than twice the upper limit of the normal range to well within the normal range. This relative hypothyroidism may have also contributed to the development of myositis in our patient, although she later recovered without the need for treatment with levothyroxine.

The onset of symptomatic myopathy occurs anywhere within the range of one week $^{(7-13)}$ to a maximum of two months (as in our case), suggesting that myositis develops early in the course of treatment. Given the debilitating nature of myositis and the propensity of rhabdomyolysis to compromise renal function, one should be vigilant to look out for the development of myositis in patients who have been newly administered ATDs. We recommend taking a history for muscle weakness and myalgia at reviews, but do not deem it necessary to routinely screen the serum CK levels of every patient, given the rarity of the complication. We also propose that the administration of the offending drug be discontinued. Replacement with an alternative drug may be useful in patients who develop myositis following treatment with ATDs. If these strategies prove to be unsuccessful, addition of levothyroxine to the treatment regimen may result in amelioration of the condition. ${ }^{(8,9,12)}$

\section{REFERENCES}

1. Swanson JW, Kelly JJ Jr, McConahey WM. Neurologic aspects of thyroid dysfunction. Mayo Clin Proc 1981; 56:504-12.

2. Bennett WR, Houston DP. Rhabdomyolysis in thyroid storm. Am J Med $1984 ; 77: 733-5$.
3. Duyff RF, Van den Bosch J, Laman DM, van Loon BJ, Linssen WH. Neuromuscular findings in thyroid dysfunction: a prospective clinical and electrodiagnostic study. J Neurol Neurosurg Psychiatry 2000; 68:750-5.

4. Horak HA, Pourmand R. Endocrine myopathies. Neurol Clin 2000; 18:203-13.

5. Kung AW. Clinical review: Thyrotoxic periodic paralysis: a diagnostic challenge. J Clin Endocrinol Metab 2006; 91:2490-5.

6. Okinaka S, Shizume K, lino S, et al. The association of periodic paralysis and hyperthyroidism in Japan. J Clin Endocrinol Metab 1957; 17:1454-9.

7. Kung AW, Ma JT, Yu YL, et al. Myopathy in acute hypothyroidism. Postgrad Med J 1987; 63:661-3.

8. Suzuki S, Ichikawa K, Nagai M, et al. Elevation of serum creatine kinase during treatment with antithyroid drugs in patients with hyperthyroidism due to Graves disease. A novel side effect of antithyroid drugs. Arch Intern Med 1997; 157:693-6.

9. Mizuno H, Sugiyama $Y$, Nishi $Y$, et al. Elevation of serum creatine kinase in response to medical treatment of Graves' disease in children. Acta Pediatr 2006; 95:243-5.

10. Shergy WJ, Caldwell DS. Polymyositis after propylthiouracil treatment for hyperthyroidism. Ann Rheum Dis 1988; 47:340-3.

11. Page SR, Nussey SS. Myositis in association with carbimazole therapy. Lancet 1989; 1:964.

12. Shaheen D, Kim CS. Myositis associated with the decline of thyroid hormone levels in thyrotoxicosis: a syndrome? Thyroid 2009; 19:1413-7.

13. Pasquier E, Genereau T, Baudrimont M, et al. Biopsy-proven myositis with microvasculitis in association with carbimazole. Lancet 1991; 338:1082-3.

14. Brent GA. Clinical Practice. Grave's disease. N Engl J Med 2008; 358:2594-605

15. Ryan DP, da Silva MR, Soong TW, et al. Mutations in potassium channel Kir2.6 cause susceptibility to thyrotoxic hypokalemic periodic paralysis. Cell 2010; 140:88-98.

16. Benavides VC, Rivkees SA. Myopathy Associated with Acute Hypothyroidism following Radioiodine Therapy for Graves Disease in an Adolescent. Int J Pediatr Endocrinol 2010; 2010. 